\title{
Thermal Effects Investigation on Electrical Properties of Silicon Solar Cells Treated by Laser Irradiation
}

\author{
Ali Pourakbar Saffara, , Bahman Deldadeh Barani ${ }^{b}$ \\ ${ }^{a}$ Laser Laboratory, Research Center of Informatic Industries, Tehran, Iran \\ ${ }^{b}$ Electronics department, Islamic Azad University (South Tehran Branch), Tehran, Iran
}

\begin{abstract}
In this paper, we were investigated electrical properties of monocrystalline and polycrystalline silicon solar cells due to laser irradiation with $650 \mathrm{~nm}$ wavelength in two states, proximate irradiation and via optics setup. Thermal effect on the cell surface due to laser irradiation was investigated on electrical properties too. Electrical parameters investigation of solar cells illustrates cell excitement via laser irradiation and efficiency decreases due to cell surface temperature increase. Monocrystalline parameters change with uniform shape due to thermal effect and laser irradiation toward polycrystalline cells.
\end{abstract}

Keywords: Crystalline, solar cell, Electrical properties, Laser, Thermal effect

Article History: Received June 02, 2014; Received in revised form August 28, 2014; Accepted Sept 18, 2014; Available online

How to Cite This Article: Saffar, A.P \& Barani, B.D. (2014) Thermal effects investigation on electrical properties of silicon solar cells treated by laser irradiation. Int. Journal of Renewable Energy Development, 3(3), 184-187.

http://dx.doi.org/10.14710/ijred.3.3.184-187

\section{Introduction}

Silicon is an important material in photovoltaic industry. Crystalline silicon is currently the dominant solar cell material for commercial application because it is so readily abundant. Solar cells provide energy of an electrical apparatus via conversion of incident photon energy to electrical energy. Solar radial energy is a source of energy that it absorbs by cells for recharging its batteries and energy saving. One major concern of the silicon solar cell industry is the reduction of reflection of incident light with an anti-reflection coating, and the other is optical confinement of the incident light by textured surface (Goetzberger et al. 2005; Green 2003). Laser processing is a very promising technique for texturing multicrystalline silicon independent on crystallographic orientation of grains compared to conventional texturing methods. The texturing of multicrystalline silicon surface using Nd:YAG laser makes it possible to increase absorption of the incident solar radiation. Laser processing is a promising method for texturization of multicrystalline

\footnotetext{
* Corresponding Author: a.pourakbar@yahoo.com
}

silicon compared to conventional texturing methods applied in used technology of solar cells (Dobrzañski et al. 2009). Crystalline-silicon (C-Si) thin film has been of great research interest for applications as active layers in thin film transistors and solar cells. In substitute of polycrystalline silicon, low-cost amorphous-silicon films can be considered for photovoltaic applications. A-Si films possess a larger band gap $(1.7 \mathrm{eV})$ than crystalline silicon. Hence, they absorb the visible part of the solar spectrum more effectively than the infrared portion of the spectrum. However, the efficiency is limited due to the absence of crystalline structure. Development of textured crystalline silicon from amorphous silicon film using a pulsed Nd:YAG laser is reported. The technique involved is laser annealing and subsequent laser nano texturing by over lapping the laser spot by $50 \%$ and $90 \%$ of the diameter (Palani et al. 2010). The amount of current produced by a photovoltaic cell is directly related to the number of photons absorbed. The lower the band gap, the more photons are absorbed and the greater the number of electrons promoted into the conduction band, and thus, available for current production. The absorption of photons, of course, will only occur if their energies exceed the band gap. 
However, such absorption does not occur precisely at the surface of materials, but rather, may penetrate deeply before being absorbed. Silicon and germanium, for example, have a much lower absorption coefficient than gallium arsenide. For this reason, thicker layers of silicon and germanium are required to absorb equivalent numbers of sufficiently energetic photons. Generated current, then, also depends on the absorptivity of a material and its thickness (Burnett 2002). Effect of pulsed Nd:YAG laser annealing $(\lambda=1.06$ $\mu \mathrm{m})$, on the efficiency of defected polycrystalline silicon solar cells have been studied (Al- Mousawy 20110). The results of experimental investigations of the AlGaAs/GaAs and GaSb PV cells intended for coupling with AlGaAs/GaAs injection lasers $(\lambda=800-870 \mathrm{~nm})$, InGaAsP/InP lasers $(\lambda=1550-1680 \mathrm{~nm})$ and iodine lasers $(\lambda=1315 \mathrm{~nm})$ are presented. CW lasers with wavelengths of $820 \mathrm{~nm}$ fabricated at the Ioffe Institute were used for testing the developed cells with aperture area of $2 \mathrm{~mm}^{2}$ at light power densities up to $50 \mathrm{~W} / \mathrm{cm}^{2}$ (Garbuzov et al. 1991). I-V characteristic measurements under illumination power densities as high as 50-250 $\mathrm{W} / \mathrm{cm}^{2}$ have been carried out using a flash Xe lamp simulator. Also, pulse $\left(\tau=10^{-3} \mathrm{~s}\right)$ iodine laser $(\lambda=1315$ $\mathrm{nm}$ ) with radiation power up to $10 \mathrm{~W}$ was used for $\mathrm{GaSb}$ cell illumination (Alexandrov et al. 1995). Photovoltaic LPC (Laser Power Converters) devices have achieved very high efficiencies. Measured efficiencies up to $56 \%$ were published for GaAs cell using prismatic covers on the cell surfaces (Andreev et al. 2003). 40\% efficiency has been reported using silicon as material for LPC when illuminated with laser light (Green et al. 1992). Photovoltaic cells illuminated with a monochromatic light source have revealed the highest ever reported photon-energy conversion efficiency. The highest measured efficiency for GaAs under laser illumination (810 nm, $43 \mathrm{~W} / \mathrm{cm}^{2}$ ) was $53.4 \%$ (Bett et al. 2008). The spectral response (SR) measurement of a solar cell is one of the richest in information tests currently performed in design and fabrication processes. The spectral response of a test cell can be measured by direct comparison with the output of a cell with the calibrated spectral response One of the most extended techniques is to use a white light source (approximating sunlight spectrum) to bias the cells, and measure the incremental spectral response to a small superimposed alternating component of monochromatic light (Silvestre et al. 1999).

\section{Materials and Methods}

The performance of the solar cell is given by the opencircuit voltage $\mathrm{V}_{\text {oc }}$, which is the voltage at zero current, and short-circuit current $\mathrm{I}_{\mathrm{sc}}$ defined as the current when the voltage equals zero, and the fill factor FF. This fill factor is defined as the ratio between the power at the maximum power point $\mathrm{P}_{\mathrm{m}}$ and the product of $\mathrm{V}_{\mathrm{oc}}$ and $\mathrm{I}_{\mathrm{sc}}$ in Eq. (1).

$$
\mathrm{FF}=\frac{\mathrm{P}_{\mathrm{m}}}{\mathrm{V}_{\mathrm{Oc}} \times \mathrm{I}_{\mathrm{sc}}}=\frac{\mathrm{V}_{\mathrm{m}} \times \mathrm{I}_{\mathrm{m}}}{\mathrm{V}_{\mathrm{Oc}} \times \mathrm{I}_{\mathrm{sc}}}
$$

$\mathrm{V}_{\mathrm{m}}$ and $\mathrm{I}_{\mathrm{m}}$ are the voltage and current at the maximum power point respectively. If the power of the incoming light $\mathrm{P}_{\text {in }}$ is now taken into account, the conversion efficiency of the solar cell $\eta$ is defined as Eq. (2).

$$
\eta=\frac{\mathrm{P}_{\mathrm{m}}}{\mathrm{P}_{\text {in }}} \times 100=\frac{\mathrm{FF} \times \mathrm{V}_{\mathrm{Oc}} \times \mathrm{I}_{\mathrm{Sc}}}{\mathrm{P}_{\text {in }}} \times 100
$$

Crystalline silicone solar cells in this work are polycrystalline and monocrystalline cells with dimensions of $96 \times 96 \times 0.31 \mathrm{~mm}^{3}$ and $31 \times 31 \times 0.25 \mathrm{~mm}^{3}$ Polycrystalline solar cell has an open-circuit voltage $\mathrm{V}_{\mathrm{oc}}=0.6 \mathrm{~V}$, short-circuit current $\mathrm{I}_{\mathrm{sc}}=120 \mathrm{~mA}$ and monocrystalline cell have a $V_{o c}=0.6 \mathrm{~V}, \mathrm{I}_{\mathrm{sc}}=100 \mathrm{~mA}$. Semiconductor laser is the $650 \mathrm{~nm}$ wavelength with $<100 \mathrm{~mW}$ output power.

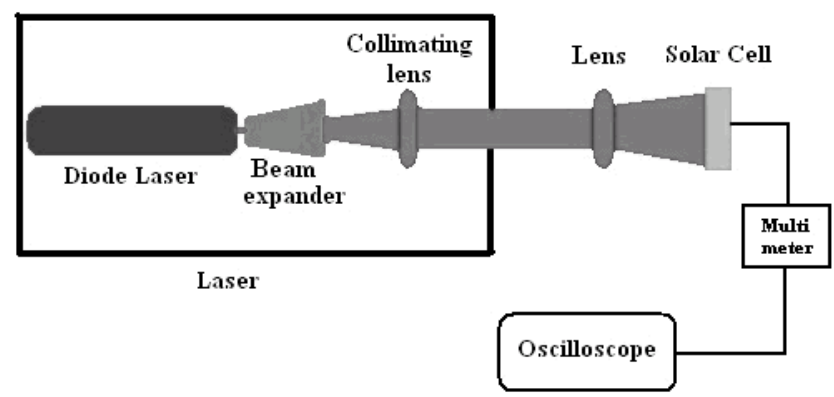

Fig. 1 Experimental setup for laser irradiation on solar cell

Electrical properties of silicon solar cells such as current, voltage and efficiency investigated due to monochromatic laser irradiation with digital multimeter and HAMEG HMO3524 oscilloscope in two states, 1- proximate irradiation and 2- irradiation via optic setup (Fig.1). Thermal effect on the solar cell surface due to laser irradiation was investigated on electrical properties too.

\section{Results and discussion}

The spectral response, SR is the parameter that determines the ratio of collected carriers with respect to the incoming photon flux at a given wavelength that for silicon solar cell illustrated in Fig.2 (Green 1987; Field 1997). There are picks of SR for silicon solar cells at 600 to $900 \mathrm{~nm}$. 


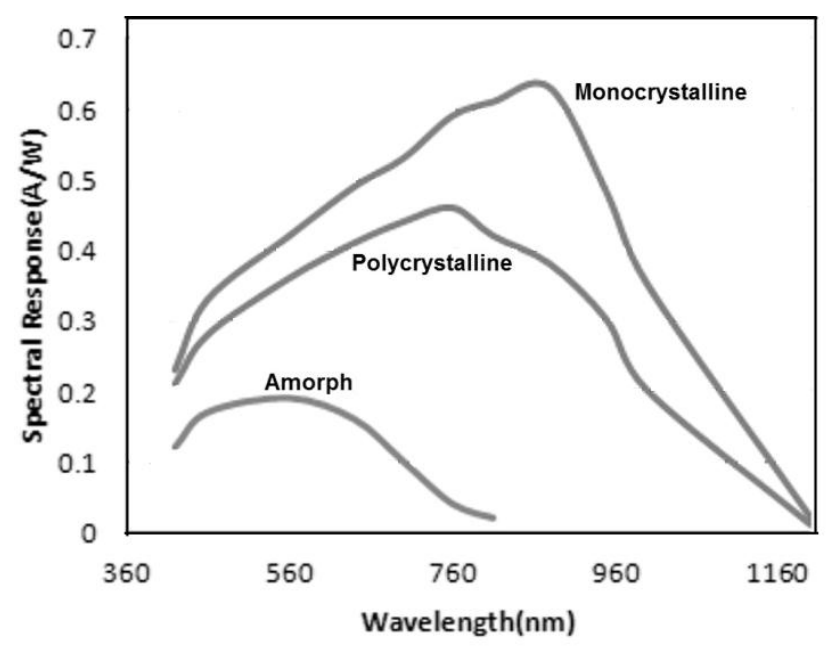

Fig. 2 Spectral response of silicon solar cells versus wavelength, a) amorphous, b) Polycrystalline, c) monocrystalline

Results from electrical and thermal tests are discussed in solar cell laser irradiation that the experimental conditions for all tests were held at room temperature. The distance between laser aperture and cell is $120 \mathrm{~cm}$, distance between the lens $(\mathrm{f}=10 \mathrm{~cm})$ and the cell varied from 30 to $90 \mathrm{~cm}$ for the different crystalline silicon cells depending on the solar cell dimensions. Average voltage, current and power output was calculated for cell/laser combination.

Table 1

Laser irradiation on polycrystalline silicon solar cell

\begin{tabular}{cccccccc}
\hline $\begin{array}{c}\mathrm{P}_{\text {in }} \\
(\mathrm{mW})\end{array}$ & $\begin{array}{c}\mathrm{V}_{\text {oc }} \\
(\mathrm{V})\end{array}$ & $\begin{array}{c}\mathrm{I}_{\mathrm{sc}} \\
(\mathrm{mA})\end{array}$ & $\begin{array}{c}\mathrm{V}_{\mathrm{m}} \\
(\mathrm{V})\end{array}$ & $\begin{array}{c}\mathrm{I}_{\mathrm{m}} \\
(\mathrm{mA})\end{array}$ & $\begin{array}{c}\mathrm{P}_{\mathrm{m}} \\
(\mathrm{mW})\end{array}$ & $\mathrm{FF}$ & $\begin{array}{c}\eta \\
(\%)\end{array}$ \\
\hline 80 & 0.6 & 100 & 0.425 & 19.6 & 8.33 & 0.138 & 10.4 \\
\hline
\end{tabular}

Table 2

Laser irradiation on monocrystalline silicon solar cell

\begin{tabular}{cccccccc}
\hline $\begin{array}{c}\mathrm{P}_{\text {in }} \\
(\mathrm{mW})\end{array}$ & $\begin{array}{c}\mathrm{V}_{\text {oc }} \\
(\mathrm{V})\end{array}$ & $\begin{array}{c}\mathrm{I}_{\mathrm{sc}} \\
(\mathrm{mA})\end{array}$ & $\begin{array}{c}\mathrm{V}_{\mathrm{m}} \\
(\mathrm{V})\end{array}$ & $\begin{array}{c}\mathrm{I}_{\mathrm{m}} \\
(\mathrm{mA})\end{array}$ & $\begin{array}{c}\mathrm{P}_{\mathrm{m}} \\
(\mathrm{mW})\end{array}$ & $\begin{array}{c}\mathrm{FF} \\
(\%)\end{array}$ & $\begin{array}{c}\eta \\
(\%)\end{array}$ \\
\hline 80 & 0.6 & 120 & 0.356 & 26.5 & 9.434 & 0.131 & 11.8
\end{tabular}

Tables (1, 2) display the data results for monocrystalline and polycrystalline cells respectively. The maximum power efficiency for polycrystalline type due to $80 \mathrm{~mW}$ laser irradiation at $650 \mathrm{~nm}$ wavelength is $11.8 \%$ and monocrystalline $10.4 \%$. Monocrystalline cell with fewer dimensions has more efficiency toward the polycrystalline cell. Since the band-gap energy of polycrystalline silicon occurs at a wavelength of $800 \mathrm{~nm}$ and monocrystalline at $900 \mathrm{~nm}$ (Fig.2), it might be possible to predict that an even higher efficiency will be seen up to the band-gap wavelength. Therefore, lasers apply with these wavelengths and more power proportion for silicon solar cell excitation.

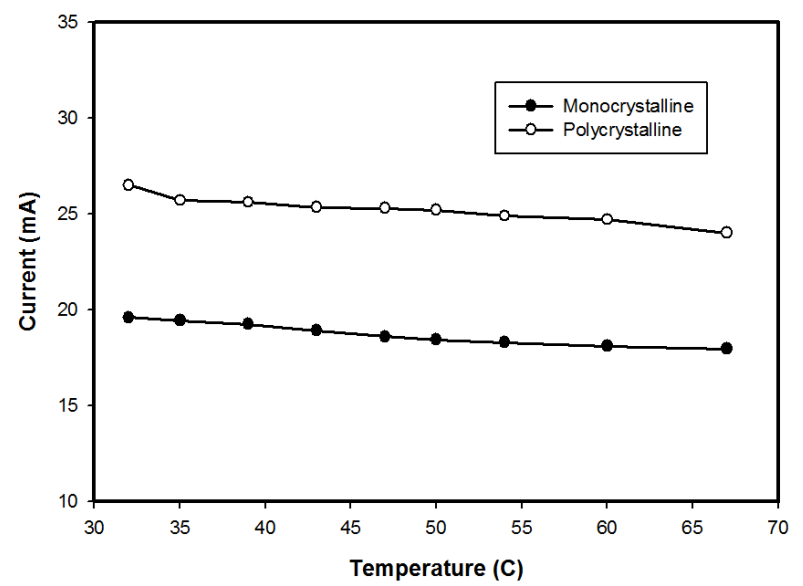

Fig. 3 Variation of current versus temperature in silicon solar cells

In order to investigate the effect of thermal changes as a cell surface to heat up, tests were performed with a heater in same laser irradiation simultaneously in ambient temperature $32^{\circ}$ to $67^{\circ}$. A thermocouple was adhesive on the forward of Si solar cell surface. In this regard, understanding the changes that take place in I-V characteristics of the laser irradiated solar cells as a function of temperature is essential. The silicon seems to be affected by the temperature change. Test results of thermal effect for silicon solar cells are shown in (Fig. 3, $4,5)$.

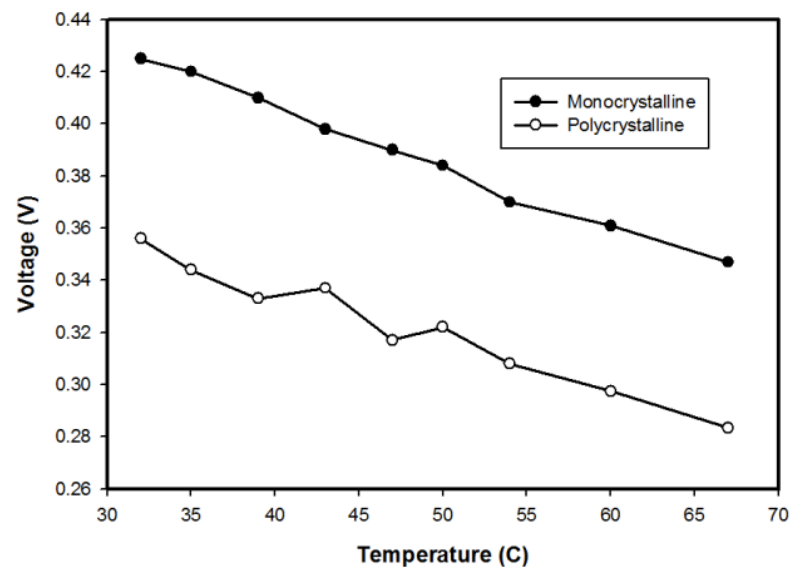

Fig. 4 Variation of voltage versus temperature in silicon solar cells

For instance, decrease of internal impedance as a function of temperature for polycrystalline cell is shown in Table 3. As it is shown, electrical parameters (current, voltage and internal impedance) and power efficiency of solar cells decrease due to environmental temperature increase. 


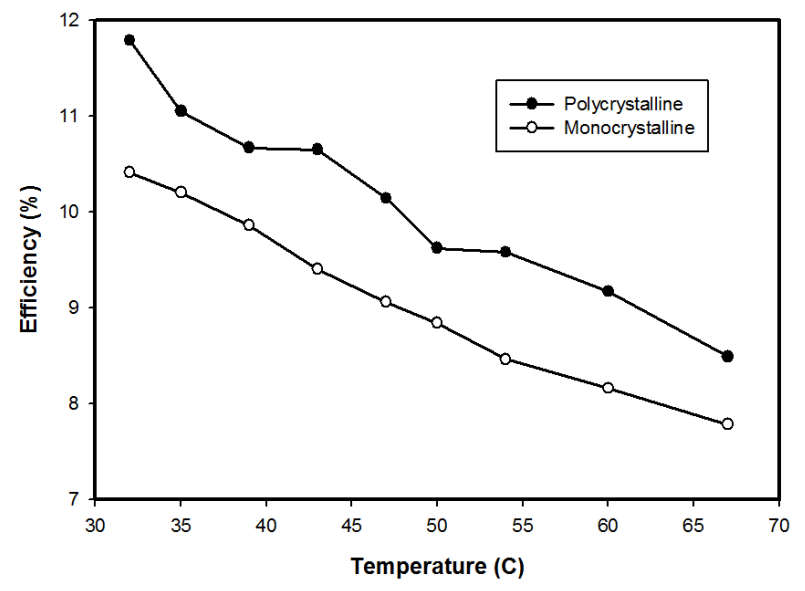

Fig. 5 Thermal effect on silicon solar cells efficiency

Silicon band-gap energy decreases with increasing solar cell and p-n junction temperature. For the constant radiation received, electrical current decrease is less than the open circuit voltage decrease; thereby the amount of cell power or efficiency decreases. Monocrystalline parameters change with uniform shape due to thermal effect and laser irradiation toward polycrystalline solar cells.

Table 3

Internal impedance as a function of temperature

\begin{tabular}{cccccccc}
\hline $\mathrm{R}(\Omega)$ & 9 & 8.94 & 8.9 & 8.8 & 8.6 & 8.5 & 8.4 \\
$\mathrm{~T}_{\mathrm{s}}\left({ }^{\circ} \mathrm{C}\right)$ & 32 & 35 & 40 & 43 & 46 & 50 & 55 \\
\hline
\end{tabular}

\section{Conclusion}

Power efficiency as $11.8 \%$ and $10.4 \%$ at $\lambda=650 \mathrm{~nm}$ have been achieved in polycrystalline and monocrystalline silicon solar cells respectively. Monocrystalline solar cell with fewer dimensions has more efficiency toward the polycrystalline cell. Lasers can apply for better excitement of crystalline silicon cells are 800-900 $\mathrm{nm}$ wavelength. The silicon seems to be affected by the temperature change. Efficiency of solar cells decreases due to environmental temperature increase.

\section{References}

Goetzberger, A., Hoffmann, V.U. (2005) Photovoltaic solar energy generation, Springer, Berlin, Heidelberg,

Green, M.A. (2003) Third generation photovoltaics: advanced solar energy conversion, Springer, Berlin, Heidelberg

Dobrzañski, L.A., Drygana, A., Panek, P., Lipiñski, M., Ziêba, P. (2009) Development of the laser method of multicrystalline silicon surface texturization, Archives of Materials Science and Engineering 38, 5-11.

Palani, I.A., Vasa, N.J., Singaperumal, M., Okada, T. (2010) Investigation on Laser-annealing and Subsequent Laser-nanotexturing of Amorphous Silicon (a-Si) Films for Photovoltaic Application, Journal of Laser Micro/Nanoengineering 5(2), 150-155.

Burnett, B. (2002) The Basic Physics and Design of III-V Multijunction Solar Cells, National Renewable Energy Laboratory (NREL), Colorado.

Al- Mousawy, A. (2010) Effect of laser annealing on defected silicon solar cells, Journal of Physics. 241.

Garbuzov, D.Z., Antonishkis, N.Y., Bondarev, A.D., et al. (1991) Highpower $0.8 \mu \mathrm{m}$ InGaAsP/GaAs SCH SQW lasers, IEEE Journal Quantum Electron 27, 1531.

Alexandrov, B.S., Fokanov, V.P., Kudryavtsev, S.N., Pavlov, A.B. (1995) Model of the direct solar-pumped iodine photodissociation laser, Laser Optics, 2773, 112.

Andreev, V., Khvostikov, V., Kalinovsky, V., et al. (2003) High current density GaAs and GaSb photovoltaic cells for laser power beaming, Proceedings 3rdWCPEC, 761.

Green, M.A., Zhao, J., Wang, A., Wenham, S. R. (1992) 45\% Efficient Silicon Photovoltaic Cell under Monochromatic Light, IEEE Electron Device Letter, 13, 317-318.

Bett, A.W., Dimroth, F., Lockenhoff, R., Oliva, E., Schubert, J. (2008) III$V$ solar cells under monochromatic illumination, 33rd IEEE Photovoltaic Specialists Conference.

Silvestre, S., Sent'is, L., Castanner, L. (1999) A Fast Low-Cost Solar Cell Spectral Response Measurement System with Accuracy Indicator, IEEE TRANSACTIONS ON INSTRUMENTATION AND MEASUREMENT, 48, 5, 944-948.

Green, M.A. (1987) High Efficiency Silicon Solar Cells, Trans Tech Publications, p. 80.

Field, H. (1997) Solar Cell Spectral Response Measurement Errors Related to Spectral Band Width and Chopped Light Waveform, 26rd IEEE Photovoltaic Specialists Conference. 